\title{
ANNOUNCEMENT: SPECIAL ISSUE
}

A special issue of Behavior Research Methods \& Instrumentation will be published as Volume 13, Number 4. The entire issue will be devoted to the subject of technology and mental health care delivery. A few of the papers to be included are:

Erdman, H. P., Greist, J. H., Klein, M. H., Jefferson, J. W., \& Getto, C. The computer psychiatrist: How far have we come? Where are we heading? How far dare we go?

Bymes, E., \& Johnson, J. H. Change technology and the implementation of automation in mental health care settings.

Sherman, P. S. A computerized CMHC clinical and management information system: Saga of a "mini" success.

Blackmore, W. R. Human software.

Scammon, M. E., Kennard, M. M., Stroebel, C. F., \& Glueck, B. C. A user-interactive graphics-based computer system for analysis of the EEG.

The price of the special issue is $\$ 12.50$. Orders may be sent to the Publications Office, 2904 Guadalupe Street, Austin, Texas 78705. 